\title{
STATISTICAL ANALYSIS \\ OF THE MACROECONOMIC INDICATORS INTERDEPENDENCE OF SELECTED COUNTRIES IN WESTERN BALKANS
}

\author{
Slobodan Subotić ${ }^{1}$ \\ Goran Mitrović ${ }^{2}$ \\ Vitomir Starčević ${ }^{3}$
}

DOI: https://doi.org/10.31410/ITEMA.S.P.2019.1

\begin{abstract}
The research conducted and included in this paper applies to the peculiarities in applying certain methods for the purpose of assessing the trends of quantitative and qualitative macroeconomic indicators in the Western Balkan countries. The research focuses particularly onto certain Western Balkan countries such as Albania, Bosnia and Herzegovina and Serbia. Contemporary statistical methods have been applied in analyzing the conjunction and mutual dependency of these countries' economies, by indicating certain unique macroeconomic indicators of their efficiency and effectiveness. In that context, indicators of gross domestic product, exports, imports and foreign direct investment have been presented both graphically and in tables, including their trend over the period from year 2000 to 2016. The analysis is based on the implementation of the econometric statistical methods of correlation and regression, as well as on the following statistic software packages: IBM SPSS ver. 21, Microsoft XLSTAT and 3B Stat ver. 1.01. A particular segment of the analysis of unique macroeconomic indicators is dedicated to the comparison of the operational effectiveness of analysed countries' economies and their rankings on the basis of each of the relevant parameters. In that respect, respective unique indicators, in addition to absolute amounts, have also been provided as "per capita" calculations, for the purpose of obtaining more realistic insight into the relative capacity of each of the countries surveyed..
\end{abstract}

Keywords: Statistical methods, Regression, Correlation

\section{INTRODUCTION}

$\mathrm{C}$

orrelation is a mutual relation of different phenomena presented by values in two or more random variables. This connection means that it is possible, with a certain degree of probability, to predict the value of a variable on the basis of the known value of another variable, the results (values) obtained can be presented in a chart (scatter plot) or by correlation coefficient. Regression analysis is one of the most commonly used statistical techniques and is considerably more complex than the correlation analysis as it represents its further elaboration. This analysis is a set of analytical techniques that are used for a more comprehensive understanding of the interdependence of observed phenomena, which further results in a regression equation (Mikić, Ralević, 2006).

This paper contains a correlation and regression analysis of macroeconomic indicators in the Western Balkan countries (Albania, Bosnia and Herzegovina, Serbia), particularly focusing on the following: 1) Gross domestic product (GDP), 2) export, 3) import and 4) Foreign Direct Investment (FDI). Research and statistical analyses cover the time period from the year 2000 to 2016, whereas the respective data had been initially appropriated based on certain economic

\footnotetext{
University of East Sarajevo, Faculty of Transportation Doboj, Doboj, Republic of Srpska, B\&H

Drina Insurance a.d. Milici, Republic of Srpska, B\&H

University of East Sarajevo, Faculty of Business Economics Bijeljina, Republic of Srpska, B\&H
} 
and statistical methods, in order to become suitable for generating specific conclusions. Namely, all of the data observed did demonstrate a remarkably unsteady trend, which was verified by means of the Augmented - Dickey - Fuller test, which is a violation of the premises for application of the regression analysis. One of the methods for resolving this issue was through logarithmic differentiation of data from successive time series. This method is used to observe the relative growth of observed phenomena instead of their specific levels. The initial data were acceptable for calculation and graphic displays of descriptive indicators, whereas the appropriated data were used for regression and correlation analysis. The analyses have been performed by means of the following statistic software packages IBM SPSS ver. 21, Microsoft XLSTAT and 3B Stat ver. 1.01.

\section{ANALYTICAL APPROACH TO RELATIONSHIP AND LINKS BETWEEN MACROECONIMC INDICATORS IN WESTERN BALKAN COUNTRIES}

\subsection{Macroeconomic indicators of Albanian economy}

The values of certain macroeconomic indicators in Albania are the basis for the analytical approach that includes the period from the year 2000 to 2016 .

Table 1. Macroeconomic indicators in Albania (billions of USD)

\begin{tabular}{|c|c|c|c|c|}
\hline Year & GDP & EXPORT & IMPORT & FDI \\
\hline 2000 & 3,680 & 0,657 & 1,418 & 0,140 \\
\hline 2001 & 4,090 & 0,754 & 1,570 & 0,210 \\
\hline 2002 & 4,440 & 0,870 & 1,968 & 0,140 \\
\hline 2003 & 5,650 & 1,150 & 2,547 & 0,180 \\
\hline 2004 & 7,460 & 1,640 & 3,310 & 0,340 \\
\hline 2005 & 8,370 & 1,910 & 3,973 & 0,260 \\
\hline 2006 & 9,130 & 2,276 & 4,430 & 0,330 \\
\hline 2007 & 10,700 & 2,707 & 5,861 & 0,650 \\
\hline 2008 & 12,880 & 3,251 & 6,716 & 1,240 \\
\hline 2009 & 12,040 & 3,368 & 6,002 & 1,340 \\
\hline 2010 & 11,920 & 3,485 & 5,788 & 1,090 \\
\hline 2011 & 12,890 & 3,730 & 6,699 & 1,050 \\
\hline 2012 & 12,340 & 3,545 & 5,865 & 0,920 \\
\hline 2013 & 14,770 & 4,167 & 6,935 & 1,250 \\
\hline 2014 & 13,220 & 3,730 & 6,239 & 1,140 \\
\hline 2015 & 11,330 & 3,103 & 5,068 & 0,910 \\
\hline 2016 & 11,860 & 3,436 & 5,434 & 1,080 \\
\hline
\end{tabular}

Source: The World Bank, http://data.worldbank.org/indicator

The data from the Table 1 have been used as the basis for calculating the descriptive indicators (shown in Table 2) such as arithmetic mean and standard deviation, as well as minimum and maximum values. Based on the values obtained, it is evident that the average GDP was 9,81 billion USD, the average export was 2,575 billion USD, import 4,69 billion USD, whereas the average FDI amounted to 0,722 billion USD. All of the given indicators share a common feature, which is the fact that all of the respective minimum values were noted the first years of observation, only to reach their maximum values in later years. 
Table 2. Descriptive indicators - Albania

\begin{tabular}{|l|c|c|c|c|}
\hline \multicolumn{1}{|c|}{ Stats } & GDP & EXPORT & IMPORT & FDI \\
\hline No. of observations & 17 & 17 & 17 & 17 \\
\hline Minimum & 3,680 & 0,657 & 1,418 & 0,140 \\
\hline Maximum & 14,770 & 4,167 & 6,935 & 1,340 \\
\hline Median & 11,330 & 3,103 & 5,434 & 0,910 \\
\hline Mean & 9,810 & 2,575 & 4,695 & 0,722 \\
\hline Standard deviation (n-1) & 3,560 & 1,184 & 1,885 & 0,454 \\
\hline
\end{tabular}

Source: Authors

The growth pace of all the indicators is best discernible from the chart (Chart 1) which clearly shows that the GDP is growing faster in comparison to other indicators, but also that the decline of imports and exports is accompanied by a sudden decline in GDP. Likewise, based on the data shown, it can be concluded that the significant growth of the FDI came in 2006 and 2007, which was then followed by a significant GDP growth.

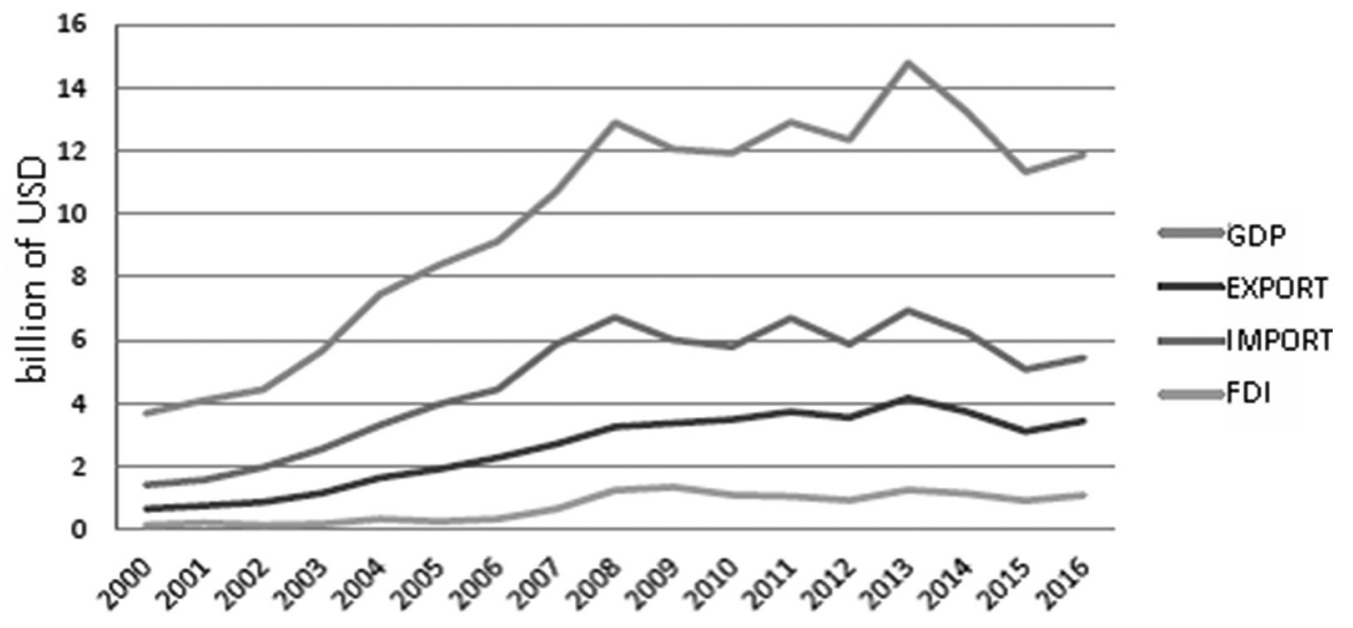

Chart 1. Macroeconomic indicators - Albania

Source: Authors

A correlation and regressive analyses were performed after the descriptive analysis. Upon checking the data through the statistic software package 3B Stat, it was found that the data were not distributed normally, therefore making it necessary to use the Spearman correlation coefficient instead of Pearson correlation coefficient. The values of these coefficients are shown in Table 3.

Table 3. Spearman correlation coefficient - Albania

\begin{tabular}{|c|c|c|c|c|c|}
\hline \multicolumn{6}{|c|}{ Correlations } \\
\hline & & GDP-ALB & EXPORT-ALB & IMPORT-ALB & FDI-ALB \\
\hline \multirow{4}{*}{ Spearman's rho } & GDP-ALB & 1,000 & $0,950^{* *}$ & $0,853^{* *}$ & $0,656^{* *}$ \\
\hline & EXPORT-ALB & $0,950^{* *}$ & 1,000 & $0,829^{* *}$ & $0,650^{* *}$ \\
\hline & IMPORT-ALB & $0,853^{* *}$ & $0,829^{* *}$ & 1,000 & 0,424 \\
\hline & FDI-ALB & $0,656^{* *}$ & $0,650^{* *}$ & 0,424 & 1,000 \\
\hline
\end{tabular}

Source: Authors

The coefficients generated indicate a direct and statistically significant conjunction of GDP to all the variables analysed. The most intensive link is between GDP and export (rho $=0,950$ ), while the weakest link is between GDP and FDI ( $\mathrm{rho}=0,656)$. All of the coefficients are statistically significant, whereas the direct link, or connection indicates that a growth of a variable 
causes a growth of another variable, which is logical in the case of exports and FDI, but it also indicates that the GDP growth also contributed to the import increase which was conditioned by the increase in expenditure, and therefore in the import as well.

The regression analysis allowed for the verification of the direction and potency of the impact of independent variables (exports, imports, FDI) onto the dependent variable (GDP).

Table 4. The value of coefficient of determination - Albania

\begin{tabular}{|l|l|l|l|l|}
\hline \multicolumn{5}{|c|}{ Model Summary $^{\mathbf{b}}$} \\
\hline \multicolumn{1}{|c|}{ Model } & \multicolumn{1}{|c|}{ R } & \multicolumn{1}{c|}{ R Square } & Adjusted R Square & Std. Error of the Estimate \\
\hline 1 & $0,975^{\text {a }}$ & 0,951 & 0,939 & 0,0133647 \\
\hline a. Predictors: (Constant), DDI-ALB, IMPORT-ALB, EXPORT-ALB \\
\hline
\end{tabular}

\section{Source: Authors}

Indicators presented in Table 4 bring us to the conclusion that a 93,9\% variation of a dependent variable is explained by the common influence of dependent variables involved in the model. The obtained $\mathrm{F}$ Test value $(\mathrm{F}=77,361 ; p$ value $=0,000)$, indicates a statistical significance of coefficient of determination $\left(\mathrm{R}^{2}\right)$, i.e. of the adjusted coefficient of determination (adjusted $\mathrm{R}^{2}$ ).

Further analysis provided data of the standardized and unstandardized $\beta$ coefficients, as well as the regression equation as well.

Table 5. Multiple linear regression coefficients - Albania

\begin{tabular}{|c|c|c|c|c|c|c|c|c|}
\hline \multicolumn{9}{|c|}{ Coefficients } \\
\hline & \multirow{2}{*}{$\begin{array}{c}\text { Model } \\
\text { B }\end{array}$} & \multicolumn{2}{|c|}{$\begin{array}{l}\text { Unstandardized } \\
\text { Coefficients }\end{array}$} & \multirow[t]{2}{*}{$\begin{array}{c}\text { Standardized } \\
\text { Coefficients }\end{array}$} & \multirow[t]{2}{*}{$\mathbf{t}$} & \multirow{2}{*}{$\begin{array}{c}\text { Sig. } \\
\text { Tolerance }\end{array}$} & \multicolumn{2}{|c|}{$\begin{array}{c}\text { Collinearity } \\
\text { Statistics }\end{array}$} \\
\hline & & Std. Error & Beta & & & & VIF & \\
\hline \multirow{4}{*}{1} & (Constant) & $-0,004$ & 0,004 & & $-0,827$ & 0,424 & & \\
\hline & $\begin{array}{l}\text { EXPORT- } \\
\text { ALB }\end{array}$ & 0,485 & 0,148 & 0,535 & 3,273 & 0,007 & 0,153 & 6,521 \\
\hline & $\begin{array}{l}\text { IMPORT- } \\
\text { ALB }\end{array}$ & 0,295 & 0,117 & 0,371 & 2,517 & 0,027 & 0,188 & 5,316 \\
\hline & FDI-ALB & 0,052 & 0,030 & 0,146 & 1,764 & 0,103 & 0,600 & 1,667 \\
\hline
\end{tabular}

Source: Authors

Data presented (Table 5) indicate the impact of every single independent variable onto GDP, and consequently, it is therefore visible that the export variable $(\beta=0,535)$ has the largest impact to GDP, followed by the import variable $(\beta=0,371)$ and finally by FDI $(\beta=0,146)$. It is important to note that the export and import variables provide a unique and statistical contribution to the regression equation ( $p$ values of 0,007 and 0,027), whereas that is not the case with the variable FDI ( $p$ value of 0,103$)$. The generated regression equation is as follows:

$$
Y=-0,004+0,485 \times X_{1}+0,295 \times X_{2}+0,052 \times X_{3}
$$

The regression equation can be interpreted as follows: the increase of export of 1 billion USD would increase GDP growth by 0.485 billion USD on the condition that other variables remain unchanged. B2 and B3 coefficients are interpreted in an identical manner. 


\subsection{Macroeconomic indicators of economy of Bosnia and Herzegovina}

Analysed macroeconomic indicators of Bosnia and Herzegovina are presented in the table 6 and represent various levels of a certain phenomenon per year.

Table 6. Macroeconomic indicators in Bosnia and Herzegovina (bn. USD)

\begin{tabular}{|c|c|c|c|c|}
\hline YEAR & GDP & EXPORT & IMPORT & FDI \\
\hline 2000 & 5,500 & 1,578 & 4,153 & 0,150 \\
\hline 2001 & 5,740 & 1,630 & 4,358 & 0,120 \\
\hline 2002 & 6,650 & 1,619 & 4,716 & 0,270 \\
\hline 2003 & 8,370 & 2,534 & 6,960 & 0,380 \\
\hline 2004 & 10,002 & 3,230 & 7,764 & 0,890 \\
\hline 2005 & 11,220 & 3,548 & 8,036 & 0,620 \\
\hline 2006 & 12,860 & 4,502 & 8,103 & 0,850 \\
\hline 2007 & 15,770 & 4,274 & 8,902 & 1,840 \\
\hline 2008 & 19,330 & 5,188 & 11,465 & 1,000 \\
\hline 2009 & 17,610 & 4,403 & 8,581 & 0,140 \\
\hline 2010 & 17,170 & 5,098 & 8,803 & 0,440 \\
\hline 2011 & 18,640 & 5,970 & 10,401 & 0,470 \\
\hline 2012 & 17,220 & 5,569 & 9,617 & 0,400 \\
\hline 2013 & 18,470 & 6,232 & 9,998 & 0,310 \\
\hline 2014 & 18,580 & 6,315 & 10,529 & 0,550 \\
\hline 2015 & 16,210 & 5,604 & 8,629 & 0,370 \\
\hline 2016 & 16,910 & 5,988 & 8,842 & 0,270 \\
\hline
\end{tabular}

Source: The World Bank, http://data.worldbank.org/indicator

The descriptive analysis of Bosnia and Herzegovina's macroeconomic status is fairly similar to previously analysed Albania, i.e. the minimum values were noted at the very beginning of observed period, only to reach their maximum values in later years, in the middle of the monitored period. The average GDP is somewhat higher than the Albanian and it amounts to 13,898 billion USD, while the average value of export and import amounts to 4,311 USD, i.e. 8,227 billion USD, respectively. The average amount of FDI per year is 0,534 billion USD.

Table 7. Descriptive indicators - Bosnia and Herzegovina

\begin{tabular}{|c|r|r|r|r|}
\hline Stats & GDP & EXPORT & IMPORT & FDI \\
\hline No. of observations & 17 & 17 & 17 & 17 \\
\hline Minimum & 5,500 & 1,578 & 4,153 & 0,120 \\
\hline Maximum & 19,330 & 6,315 & 11,465 & 1,840 \\
\hline Median & 16,210 & 4,502 & 8,629 & 0,400 \\
\hline Mean & 13,898 & 4,311 & 8,227 & 0,534 \\
\hline Standard deviation (n-1) & 4,948 & 1,673 & 2,133 & 0,426 \\
\hline
\end{tabular}

Sources: Authors

The movement of observed macroeconomic indicators is more clearly shown by the graphic illustration of presented data (Chart 2) derived from Table 7. The chart shows that FDI reached their maximum in year 2006, and consequently the value of FDI, exports and imports reached their peak value in the following year. The world economic crisis, which struck afterwards, significantly influenced the decline of all macroeconomic parameters, as clearly shown on chart 2. 


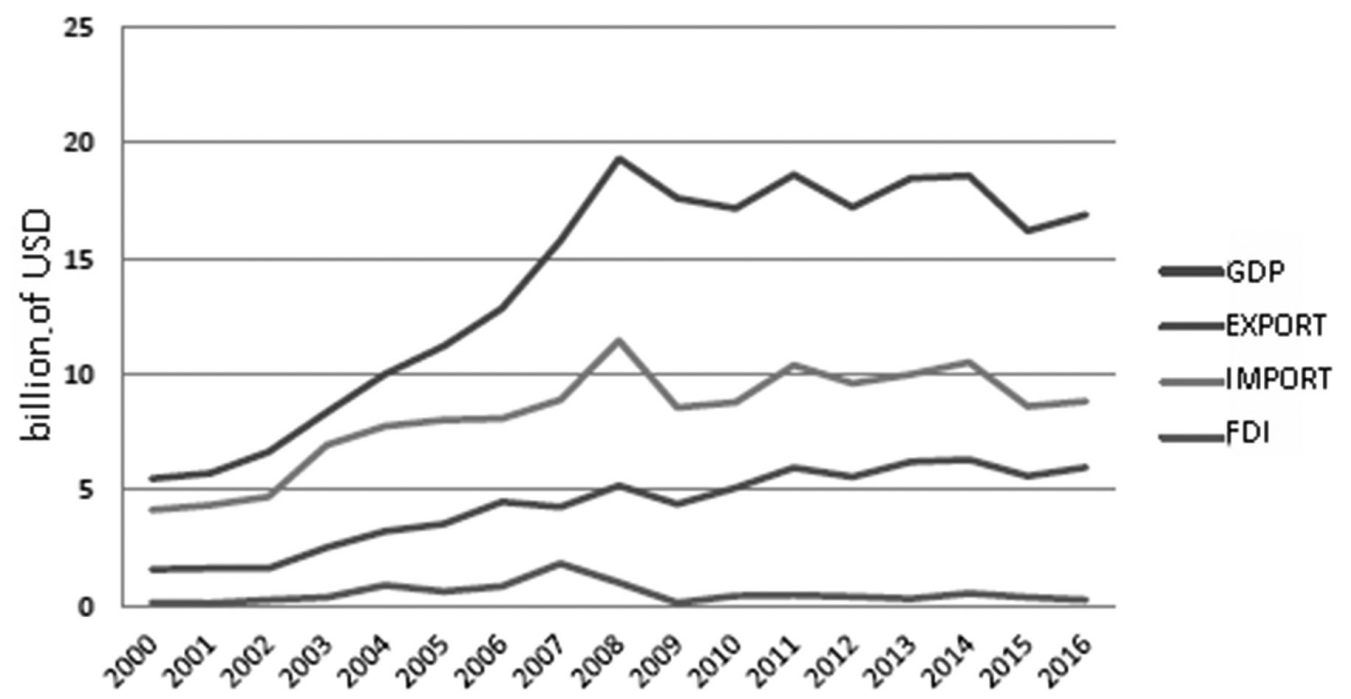

Chart 2. Macroeconomic indicators - Bosnia and Herzegovina

Source: Authors

The results of the correlation and regression analyses have been shown in the following tables. On the basis of the data from the Table 8 , it is evident that there is a statistically significant correlation link between GDP and exports and GDP and imports (Rho $=0,626$ and rho $=0,809)$, whereas there is no statistically significant link between FDI and GDP. Both of the correlation coefficients are positive, thus indicating that the subject relationship is direct, i.e. that the growth of one dependent variable consequently increases the value of the other one.

Table 8. Spearman's correlation coefficients - Bosnia and Herzegovina

\begin{tabular}{|c|c|c|c|c|c|}
\hline \multicolumn{6}{|c|}{ Correlations } \\
\hline & & GDP-B\&H & EXPORT-B\&H & IMPORT-B\&H & FDI-B\&H \\
\hline \multirow{4}{*}{ Spearman's rho } & GDP- B\&H & 1,000 & $0,626^{* *}$ & $0,809^{* *}$ & 0,344 \\
\hline & EXPORT-B\&H & $0,626^{* *}$ & 1,000 & $0,597^{*}$ & 0,309 \\
\hline & IMPORT- B\&H & $0,809^{* *}$ & $0,597^{*}$ & 1,000 & 0,388 \\
\hline & FDI- B\&H & 0,344 & 0,309 & 0,388 & 1,000 \\
\hline
\end{tabular}

Source: Authors

The regression analysis showed that $61,7 \%$ of GDP variability is determined by the variability of other assessed macroeconomic indicators, i.e., by a respective model. This outcome is statistically significant, as confirmed by the $\mathrm{F}$ test $(F=9,069 ; p$ value $=0,002)$.

Table 9. The value of the coefficient of determination - Bosnia and Herzegovina

\begin{tabular}{|l|l|l|l|l|}
\hline \multicolumn{5}{|c|}{ Model Summary $^{\mathbf{b}}$} \\
\hline \multicolumn{1}{|c|}{ Model } & \multicolumn{1}{|c|}{ R } & \multicolumn{1}{c|}{ R Square } & \multicolumn{1}{c|}{ Adjusted R Square } & Std. Error of the Estimate \\
\hline 1 & $0,833^{\text {a }}$ & 0,694 & 0,617 & 0,0303978 \\
\hline \multicolumn{2}{|l}{ a. Predictors: (Constant), FDI-BIH, EXPORT-BIH, IMPORT-B\&H } \\
\hline
\end{tabular}

Source: Authors

Further analysis was used to calculate and present the B and $\beta$ coefficients, as well as the regression equation. 
Table 10. Multiple linear regression coefficients $-\mathrm{B} \& \mathrm{H}$

\begin{tabular}{|c|c|c|c|c|c|c|c|c|}
\hline \multicolumn{9}{|c|}{ Coefficients a } \\
\hline & \multirow{2}{*}{$\begin{array}{c}\text { Model } \\
\text { B }\end{array}$} & \multicolumn{2}{|c|}{$\begin{array}{c}\text { Unstandardized } \\
\text { Coefficients }\end{array}$} & \multirow[t]{2}{*}{$\begin{array}{c}\text { Standardized } \\
\text { Coefficients }\end{array}$} & \multirow{2}{*}{$\mathbf{t}$} & \multirow{2}{*}{$\begin{array}{c}\text { Sig. } \\
\text { Tolerance }\end{array}$} & \multicolumn{2}{|c|}{$\begin{array}{c}\text { Collinearity } \\
\text { Statistics }\end{array}$} \\
\hline & & $\begin{array}{l}\text { Std. } \\
\text { Error }\end{array}$ & Beta & & & & VIF & \\
\hline \multirow{4}{*}{1} & (Constant) & 0,018 & 0,009 & & 2,010 & 0,067 & & \\
\hline & $\begin{array}{c}\text { EXPORT- } \\
\text { B\&H }\end{array}$ & 0,019 & 0,201 & 0,026 & ,093 & 0,927 & 0,332 & 3,016 \\
\hline & $\begin{array}{c}\text { IMPORT- } \\
\text { B\&H }\end{array}$ & 0,578 & 0,209 & 0,805 & 2,758 & 0,017 & 0,299 & 3,343 \\
\hline & FDI- B\&H & 0,002 & 0,027 & 0,013 & 0,072 & 0,944 & 0,762 & 1,313 \\
\hline
\end{tabular}

Source: Authors

Table 10 shows the results obtained. It should be noted that only B2 value is statistically significant, that is, that only "import" variable provides a unique statistically significant contribution to the regression equation. The values of standardized $\beta$ coefficients speak in favour of the above, as it is clear that the impact of import is 0,805 , of export 0,026 , and of FDI only 0,013 . The regression equation is as follows:

$$
Y=0,018+0,019 \times X_{1}+0,0578 \times X_{2}+0,002 \times X_{3}
$$

The regression equation is interpreted in the same way as in the previous case, a 1 billion USD increase in export will cause the GDP growth of 0,578 billion USD.

\subsection{Macroeconomic indicators of the economy of Serbia}

The data of the macroeconomic indicators of Serbia are shown in the following table, on the basis of which a detailed analysis has been performed.

Table 11. Macroeconomic indicators in Serbia (bn. USD)

\begin{tabular}{|c|c|c|c|c|}
\hline YEAR & GDP & EXPORT & IMPORT & FDI \\
\hline 2000 & 6,540 & 0,644 & 0,936 & 0,050 \\
\hline 2001 & 12,260 & 2,751 & 4,627 & 0,180 \\
\hline 2002 & 16,170 & 3,337 & 6,261 & 0,500 \\
\hline 2003 & 21,180 & 4,651 & 8,377 & 1,460 \\
\hline 2004 & 24,860 & 6,019 & 12,587 & 0,960 \\
\hline 2005 & 26,250 & 7,124 & 12,372 & 1,580 \\
\hline 2006 & 30,60 & 9,260 & 15,481 & 4,250 \\
\hline 2007 & 40,290 & 11,426 & 21,217 & 4,420 \\
\hline 2008 & 49,260 & 14,340 & 26,664 & 4,050 \\
\hline 2009 & 42,610 & 11,437 & 18,212 & 2,920 \\
\hline 2010 & 39,440 & 12,988 & 18,900 & 1,700 \\
\hline 2011 & 46,460 & 15,782 & 22,937 & 4,930 \\
\hline 2012 & 40,700 & 15,026 & 21,811 & 1,270 \\
\hline 2013 & 45,520 & 18,754 & 23,625 & 2,060 \\
\hline 2014 & 44,210 & 19,174 & 23,971 & 2,000 \\
\hline 2015 & 37,460 & 17,483 & 21,135 & 2,340 \\
\hline 2016 & 38,300 & 19,158 & 22,011 & 2,300 \\
\hline
\end{tabular}

Source: The World Bank, http://data.worldbank.org/indicator 
The same features of the two countries previously analysed are also notable in descriptive indicators of Serbia, as displayed in Table 12. The average GDP amounts to 33,065 billion USD, the average export over the monitored period amounts to 11,138 billion USD, import 16,537 billion USD, and the average amount of FDI is 2,175 billion USD. Minimum values were registered in the first observed year, only to continue their increase in each subsequent year and to reached their maximum right before the world economic crisis (apart from the FDI).

Table 12. Descriptive indicators- Serbia

\begin{tabular}{|l|r|r|r|r|}
\hline \multicolumn{1}{|c|}{ Stats } & GDP & EXPORT & IMPORT & FDI \\
\hline No. of observations & 17 & 17 & 17 & 17 \\
\hline Minimum & 6,540 & 0,644 & 0,936 & 0,050 \\
\hline Maximum & 49,260 & 19,174 & 26,664 & 4,930 \\
\hline Median & 38,300 & 11,437 & 18,900 & 2,000 \\
\hline Mean & 33,065 & 11,138 & 16,537 & 2,175 \\
\hline Standard deviation (n-1) & 12,973 & 6,159 & 7,704 & 1,495 \\
\hline Stats & 0,381 & 0,536 & 0,452 & 0,667 \\
\hline
\end{tabular}

Source: Authors

Graphic display of data from the Table 12 shows that GDP, export and import reached their maximum values in year 2008, whereas the FDI variable reached its maximum in 2001. Likewise, a notable increase of all the indications is evident until year 2008, followed by a two-year decline of the same indicators.

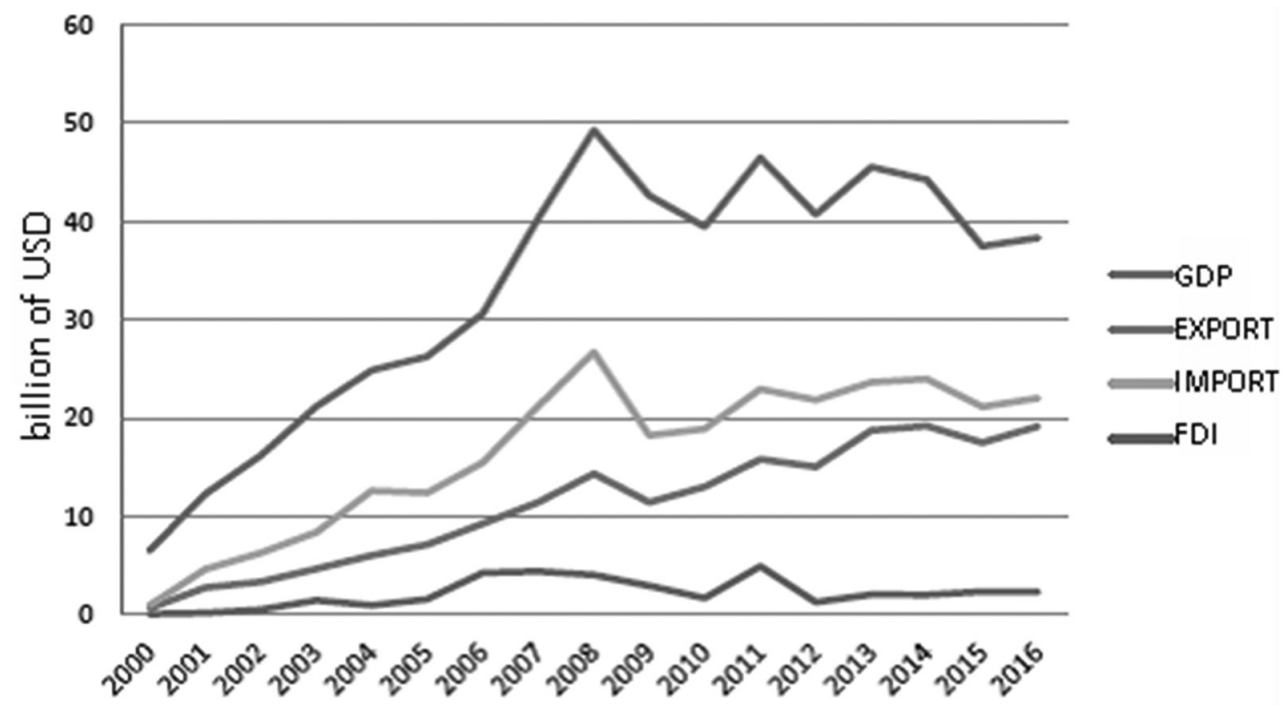

Chart 3. Macroeconomic indicators - Serbia

Source: Authors

The results of correlation and regression analyses are shown in the following table. By means of correlation analysis (Table 13), it was found that there was a strong and direct correlation link between GDP, export and import ( $r h o=0,818$ and $r h o=0,924)$, while the link between GDP and FDI is somewhat weaker, but statistically significant nevertheless $(r h o=0,621)$. Likewise, a strong correlation link was found between export and import $(r h o=0,818)$. 
Table 13. Spearman's correlation coefficients - Serbia

\begin{tabular}{|c|c|l|l|l|l|}
\hline \multicolumn{7}{|c|}{ Correlations } \\
\hline & GDP-SRB & \multicolumn{1}{|c|}{ GDP-SRB } & EXPORT-SRB & \multicolumn{1}{c|}{ IMPORT-SRB } & \multicolumn{1}{c|}{ FDI-SRB } \\
\hline \multirow{4}{*}{ Spearman's rho } & 1,000 & $0,818^{* *}$ & $0,924^{* *}$ & $0,621^{*}$ \\
\cline { 2 - 7 } & EXPORT-SRB & $0,818^{* *}$ & 1,000 &, $862^{* *}$ & $0,544^{*}$ \\
\cline { 2 - 7 } & IMPORT-SRB & $0,924^{* *}$ & $0,862^{* *}$ & 1,000 & 0,432 \\
\cline { 2 - 7 } & FDI-SRB & $0,621^{*}$ & $0,544^{*}$ & 0,432 & 1,000 \\
\hline
\end{tabular}

Source: Authors

In order to avoid multicollinearity among the independent variables, the export variable has been excluded from the regression analysis, as it is in a strong correlational link with the import variable. This relationship has led to multicollinearity where two independent variables generate the same or similar contribution to determining a dependent variable. By means of regression, it was found that $86,00 \%$ of GDP variability is determined by the variability of independent variables (imports, FDI). The $\mathrm{F}$ test $(F=32,022 ; p$ value $=0,000)$ has shown that the contribution of independent variables in explaining GDP changes is statistically significant.

Table 14. The value of coefficient of determination - Serbia

\begin{tabular}{|l|l|l|l|l|}
\hline \multicolumn{5}{|c|}{ Model Summary $^{\mathbf{b}}$} \\
\hline \multicolumn{1}{|c|}{ Model } & \multicolumn{1}{|c|}{ R } & \multicolumn{1}{c|}{ R Square } & Adjusted R Square & Std. Error of the Estimate \\
\hline 1 & $0,937^{\mathrm{a}}$ & 0,879 & 0,860 & 0,0332835 \\
\hline a. Predictors: (Constant), FDI-SRB, IMPORT-SRB \\
\hline
\end{tabular}

Source: Authors

By observing data from the Table 15, it can be concluded that B2 and B3 coefficients (import and FDI) provide a unique and statistically significant contribution to the elaboration of GDP ( $t$ $=6,645 ; p$ value $=0,000 ; t=2,733 ; p$ value $=0,017$.

Table 15. Multiple linear regression coefficients - Serbia

\begin{tabular}{|c|c|c|c|c|c|c|c|c|}
\hline \multicolumn{9}{|c|}{ Coefficients $^{\mathrm{a}}$} \\
\hline & \multirow{2}{*}{$\begin{array}{l}\text { Model } \\
\text { B }\end{array}$} & $\begin{array}{r}\text { Unst } \\
\text { Co } \\
\end{array}$ & $\begin{array}{l}\text { ndardized } \\
\text { fficients }\end{array}$ & $\begin{array}{c}\text { Standardized } \\
\text { Coefficients }\end{array}$ & \multirow{2}{*}{$\mathbf{t}$} & \multirow{2}{*}{$\begin{array}{c}\text { Sig. } \\
\text { Tolerance }\end{array}$} & \multicolumn{2}{|c|}{$\begin{array}{c}\text { Collinearity } \\
\text { Statistics }\end{array}$} \\
\hline & & $\begin{array}{l}\text { Std. } \\
\text { Error }\end{array}$ & Beta & & & & VIF & \\
\hline \multirow{3}{*}{1} & (Constant) & 0,008 & 0,009 & & 0,876 & 0,397 & & \\
\hline & IMPORT-SRB & 0,361 & 0,054 & 0,744 & 6,645 & 0,000 & 0,743 & 1,346 \\
\hline & FDI-SRB & 0,086 & 0,032 & 0,306 & 2,733 & 0,017 & 0,743 & 1,346 \\
\hline
\end{tabular}

Source: Authors

By comparing values in beta column, we come to the conclusion that the influence of import is more than twice of that of FDI $(0,744>0,306)$. The regression equation generated based on the data obtained is as follows:

$$
Y=0,008+0,361 \times X_{1}+0,086 \times X_{2}
$$

And it is interpreted identically as with the previous countries. 


\section{COMPARATIVE ANALYSIS OF MACROECONOMIC INDICATORS IN WESTERN BALKAN COUNTRIES}

Comparative analysis of the gross domestic product indicators per capita is performed on the basis of indicators taken from the World Bank website, as shown in Table 16.

Table 16. GDP per capita in Western Balkan countries and the EU (USD)

\begin{tabular}{|c|c|c|c|c|}
\hline Year & Albania & B\&H & Serbia & EU \\
\hline 2000 & 1,175 & 1,462 & 870 & 18,244 \\
\hline 2001 & 1,327 & 1,524 & 1,524 & 18,407 \\
\hline 2002 & 1,454 & 1,762 & 2,150 & 20,018 \\
\hline 2003 & 1,891 & 2,215 & 2,832 & 24,278 \\
\hline 2004 & 2,417 & 2,651 & 3,331 & 27,922 \\
\hline 2005 & 2,709 & 2,968 & 3,528 & 29,093 \\
\hline 2006 & 3,005 & 3,404 & 4,130 & 30,923 \\
\hline 2007 & 3,603 & 4,180 & 5,458 & 35,594 \\
\hline 2008 & 4,370 & 5,078 & 6,702 & 38,136 \\
\hline 2009 & 4,114 & 4,701 & 5,821 & 33,979 \\
\hline 2010 & 4,094 & 4,614 & 5,412 & 33,677 \\
\hline 2011 & 4,437 & 5,054 & 6,423 & 36,409 \\
\hline 2012 & 4,248 & 4,722 & 5,659 & 34,253 \\
\hline 2013 & 4,413 & 5,211 & 6,354 & 35,388 \\
\hline 2014 & 4,579 & 5,204 & 6,200 & 36,760 \\
\hline 2015 & 3,953 & 4,584 & 5,237 & 32,207 \\
\hline 2016 & 4,132 & 4,808 & 5,426 & 32,260 \\
\hline
\end{tabular}

Source: The World Bank, https://data.worldbank.org/indicator

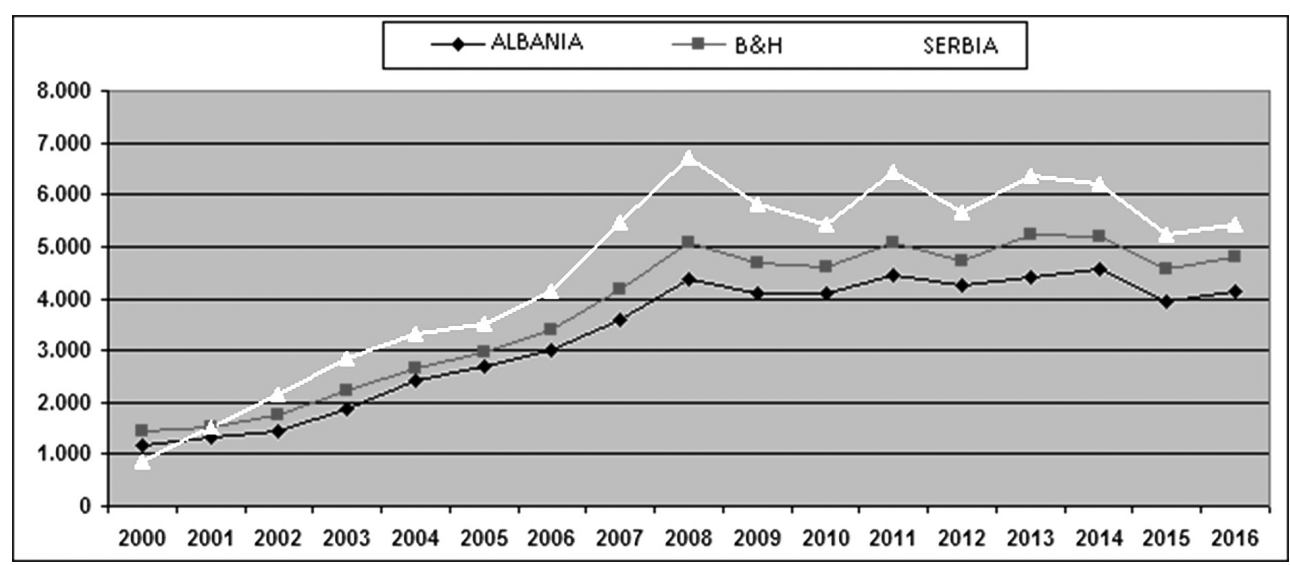

Chart 4. Movement of GDP per capita of the Western Balkan countries

Source: Authors

By monitoring movement of GDP per capita of three Western Balkans countries, and based on the indicators from Table 16, it can be said that the trend of GDP per capita of all countries had rising-falling properties. All of the countries recorded GDP per capita decline in years 2009, 2010, 2012 and 2015. Albania had the largest decline of GDP per capita in 2015 by 13,67\% compared to the year before. Bosnia and Herzegovina, unlike Albania, registered a less severe decline in GDP per capita in 2015, amounting to 11,91\%. A similar situation was also in Serbia, that registered the largest GDP decline per capita in $2015(15,33 \%)$ that was somewhat more intense than the one in Bosnia and Herzegovina. 


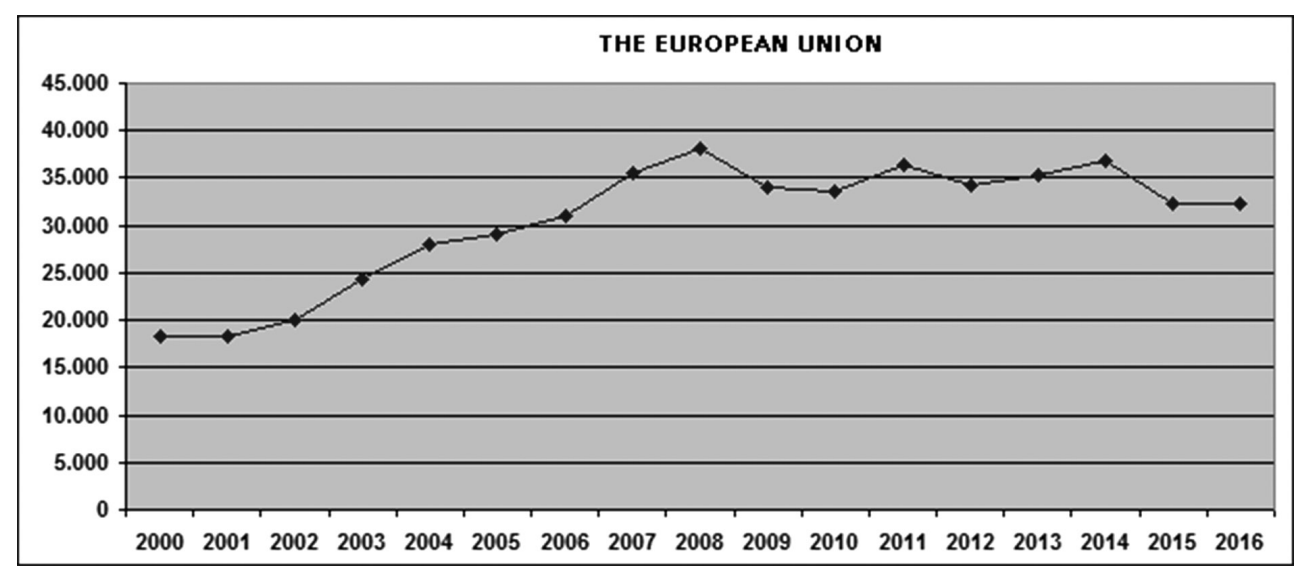

Chart 5. Movement of GDP per capita of the EU

Source: Authors

If we were to analyse the movement of GDP per capita of the European Union (Table 16), it becomes evident that the decline of this macroeconomic indicator has been recorded several times. The drastic decline of GDP per capita was notable in year 2009 by $10,90 \%$ compared to 2008. The mild decline of this indicator was recorded in year $2010(0,88 \%)$, whereas in 2012 the decline of GDP per capita amounted to 5,92\%, and in 2015 it was $12,38 \%$. It is important to point out that the decline of GDP per capita in the European Union was followed by the decline of this particular indicator in all of the Western Balkan countries, with the most pronounced effect in 2015 as it was the case with the European Union. This indicates the existence of a cause and effect link of the European Union economies and of the Western Balkan countries' economies. The movements of GDP per capita of the European Union have also been presented in the Chart 5.

\section{CONCLUSION}

The countries observed share several distinctive macroeconomic indicators. It should be noted that the subject countries were under the great influence of the recession factors to 2000 . The cause of a ten-year recession in the assessed countries was a very unfavourable political and security situation, which caused a major decline in economic activity, a decline in social and individual standards, a reduction in consumption and investment, and nearly the complete exclusion of foreign direct investment. All of the above factors resulted in a massive decline in GDP.

Consolidation and establishment of elementary economic conditions have created preconditions for the significant growth of GDP percentage, which in some of the subject countries amounted even up to $20 \%$, which is very uncommon in stable and developed economies. The common feature for all the given countries was that they all registered a high percentage of GDP growth in the first part over the period from 2000 to 2007, whereas in the second part of the assessed period (2008-2016), their GDP growth rates were significantly lower, sometimes stagnant, and even registering a few cases of recession, triggered by the one occurring on the global scale. The above is a completely normal sequence of events, given the fact that in the first period, up to year 2007, the subject countries had used up their natural and comparative advantages in raising their economic activity. The reason for the slower GDP growth in the second part of the monitored period (2008-2016) lies in much greater exposure to the impacts of the world market, competitiveness, insufficient technological development, traffic infrastructure conditions, level of education system and other macroeconomic indicators. 
The final conclusion related to the GDP growth of these countries is that all of them recorded a high level of growth expressed in absolute indications.

The next common feature of the observed countries is that each of them had a high foreign trade deficit that was the highest at the beginning of the monitored period (import coverage by export was $40 \%$ ), only for the foreign trade deficit to be significantly reduced in the following years (with some countries reaching up to $85 \%$ ). The reason for the high foreign trade deficit lies in the fact that in the beginning of the assessed period there was a great increase in demand for goods that the local economy was not able to provide, i.e. the inability of the local economy to enable better import coverage by export.

By analysing the set model from the aspect of FDI influence onto the GDP growth, it can be stated that in the initial observed period, the influence on GDP growth was less notable, as the predominant was the influence of the consolidation of the economic system and growth of the economic activity, as well as that the FDI had a positive effect initially. Over time the FDI had a growing impact on GDP growth in terms of enhancing the competitiveness of the assessed countries. Based on the research results, it can be concluded that in the upcoming period, FDI will have a continuously growing impact on GDP growth, as well as on the reduction and elimination of the foreign trade deficit.

The importance of FDI growth does not only lie in the fact that it positively affects GDP growth, but it also has a positive impact on the balance of payments as well as on the chronic issue of the countries suffering from a budget deficit. The FDI ultimately have a positive impact on the balance of entire public finances of the observed states. It can be said that the influx of FDI is not nearly at a level that is possible to be achieved by utilising comparative advantages of this region. It should be noted that the observed countries are still in the process of transition with currently ongoing risks (security risks, political risks, rule of law, corruption, implementation of international standards and other risks) that have an unfavourable impact on FDI. The elimination of those risks will manifest the most important preconditions that attract the FDI, particularly referring to the cheap labour, unused natural resources, geostrategic position, traffic infrastructure, market proximity, etc.

Generally speaking, in all three assessed Western Balkan countries, regardless of their unequal level of economic development, descriptive indicators point to the conclusion that the changes in export and import significantly affect the value of GDP. The correlation analysis indicates a significant statistical link of GDP with the exports and imports in all of the subject countries, while only Serbia has registered somewhat weaker statistical link between GDP and the FDI variable. The results of the multiple linear regression coefficient show that the import variable, in all three countries, has the greatest statistical impact onto the regression equation, i.e., on the value of GDP. Unlike the other countries, in Albania, the export variable also has a statistical influence on the regression equation, while this statistical significance in Serbia is somewhat less pronounced with the FDI variable as well. 


\section{REFERENCES}

http://www.bg.ac.rs/files/sr/studije/studije-uni/Uvod_statisticke_metode_istrazivanja.pdf http://www.ef.uns.ac.rs/Download/statistika/ http://www.e-statistika.rs/Article/Display/korelacija-i-regresiona-analiza https://data.worldbank.org/indicator/NY.GDP.MKTP.CD?locations=AL-BA-RS https://e-statistika.rs/Article/Display/korelacija-i-regresiona-analiza https://unctad.org/en/PublicationsLibrary/wir2012_embargoed_en.pdf, https://unctad.org/en/PublicationsLibrary/wir2018_en.pdf

Lovrić, M., Komić, J., Stević, S. (2017). Statistics Analysis - Methods and Application (orig. Statistička analiza-metodi i primjena), $2^{\text {nd }}$ abridged edition, Public Institution - National and University Library of the Republic of Srpska, Banja Luka.

Malešević, Đ., Starčević, V. (2010). Business Analysis (orig. Poslovna analiza), University of East Sarajevo, Faculty of Business Economics in Bijeljina.

Mikić, Đ., Ralević, N. (2006). Statistics Methods in Management (orig. Statističke metode u menadžmentu), PanEuropean University Apeiron, Banja Luka.

The World Bank, http//data.worldbank.org/indicator 